\title{
Pengaruh qualification mismatch terhadap upah tenaga kerja di Indonesia
}

\author{
Ernawaty Hasibuan ${ }^{1}$, Dwini Handayani ${ }^{2}$ \\ ${ }^{1}$ Kementerian Perindustrian, erna.hasibuan@ymail.com; \\ ${ }^{2}$ Fakultas Ekonomi dan Bisnis, Universitas Indonesia, dwiniarianto@yahoo.com.
}

\begin{abstract}
ABSTRAK
Penelitian ini bertujuan untuk memeriksa kejadian qualification mismatch dan pengaruhnya terhadap upah tenaga kerja di Indonesia. Dengan menggunakan SAKERNAS 2018, qualification mismatch diidentifikasi menggunakan metode normatif. Vertical mismatch diperoleh dengan membandingkan tingkat pendidikan dan golongan pekerjaan (KBJI 1 digit), sedangkan horizontal mismatch membandingkan klasifikasi jurusan pendidikan (3 digit ISCED-F) dan klasifikasi jabatan (KBJI 3 digit). Pada tahun 2018, tenaga kerja yang mengalami undereducation berjumlah sebesar 4,6\% dan overeducation sebesar 27,9\%. Sedangkan kejadian field of study mismatch terjadi pada $68,4 \%$ tenaga kerja di Indonesia. Pengaruh qualification mismatch terhadap upah tenaga kerja diestimasi dengan menggunakan metode ordinary least square. Hasil menunjukkan bahwa terdapat wage premium sebesar 5,24\%$6,24 \%$ pada tenaga kerja yang mengalami undereducation. Wage penalty sebesar 6,26\%-7,50\% diperoleh tenaga kerja yang mengalami overeducation, sedangkan yang mengalami field of study mismatch sebesar 5,89\%-6,80\%.
\end{abstract}

Kata Kunci: Undereducation, overeducation, field of study mismatch, upah tenaga kerja.

Klasifikasi JEL: I26, J24, J31

\section{ABSTRACT}

This study aims to examine qualification mismatch incidence and its effect on labor earning in Indonesia using SAKERNAS 2018. Qualification mismatch is identified using the normative method. A vertical mismatch is obtained by comparing education levels and 1-digit KBJI, while a horizontal mismatch compares 3-digits ISCED-F and 3-digits KBJI. In 2018, there were 4.6\% undereducated labor and 27.9\% overeducated labor. While the field of study mismatch occurred in $68.4 \%$ of the labor force in Indonesia. The effect of qualification mismatch on labor earning is estimated using the ordinary least square method. The results show that there is a 5.24\% - $6.24 \%$ wage premium for undereducated laborers. Wage penalty of $6.28 \%-7.52 \%$ were suffered by overeducated labors, while those who experienced field of study mismatch of $5.89 \%-6.80 \%$.

Keywords: Undereducation, overeducation, field of study mismatch, labor earnings.

JEL Classification: I26, J24, J31

\section{PENDAHULUAN}

Dalam beberapa tahun terakhir, tingkat pendidikan yang dimiliki tenaga kerja Indonesia semakin tinggi (Di Gropello dkk., 2011; Suharti, 2013). Berdasarkan data BPS dalam kurun waktu 2008 sampai 2018, peningkatan jumlah tenaga kerja lulusan pendidikan tinggi mencapai 131,33\%, lulusan SMK sebesar 67,47\%, dan lulusan SMA sebesar 28,31\%. Sementara proporsi tenaga kerja dengan pendidikan sekolah menengah pertama ke bawah terus mengalami penurunan. Hal ini menunjukkan perubahan struktur angkatan kerja Indonesia, dimana jumlah tenaga kerja terdidik semakin tinggi. Peningkatan capaian pendidikan tenaga kerja dapat mengindikasikan modal manusia yang dimiliki semakin tinggi. Dengan meningkatnya kemampuan dan keterampilan tenaga kerja maka diharapkan akan meningkatkan produktivitas tenaga kerja serta tingkat pengembalian investasi dalam pendidikan (Becker, 1975; Schultz, 1961). 


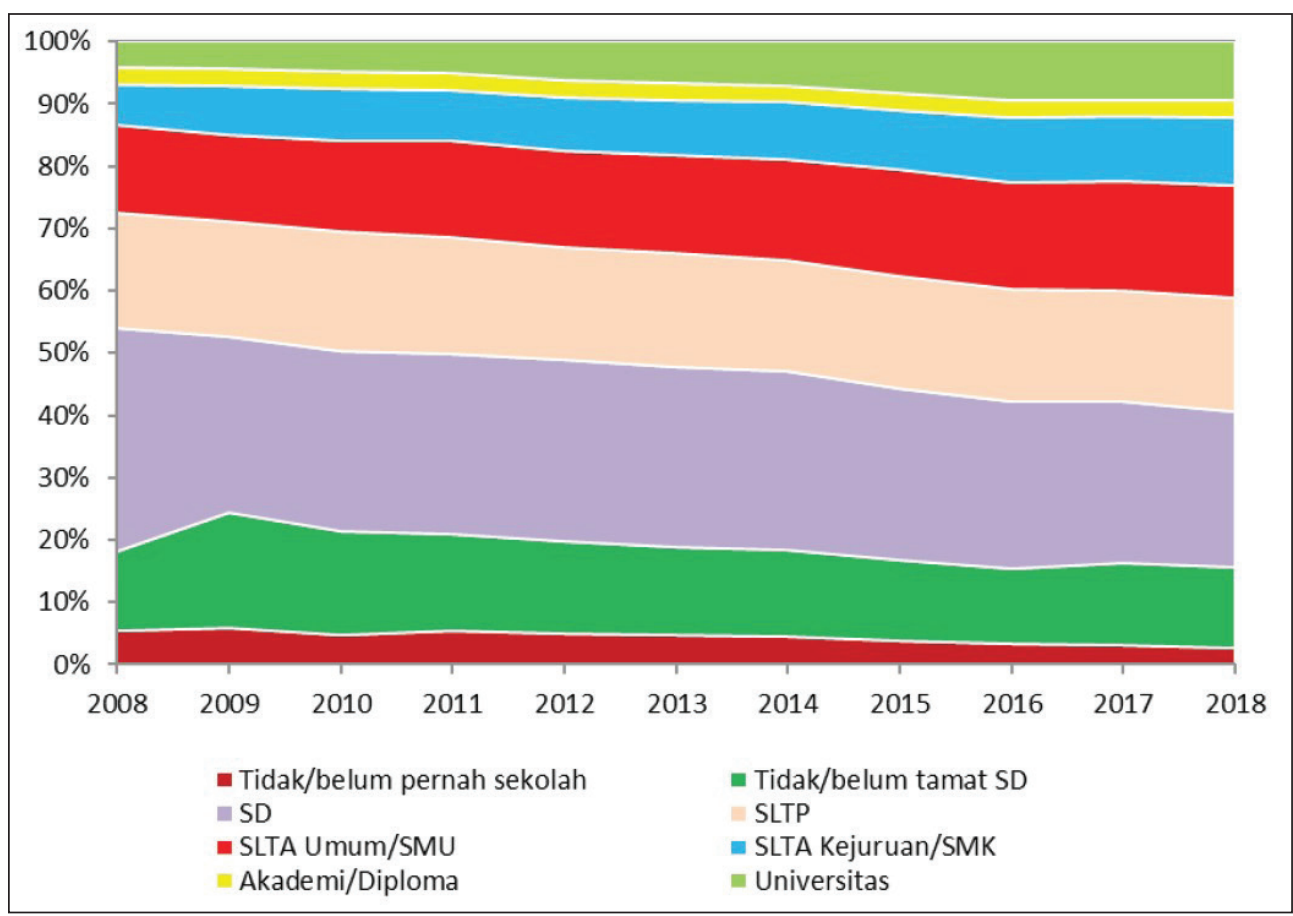

Sumber: SAKERNAS BPS (2018), diolah

Gambar 1. Tingkat Tenaga Kerja Berdasarkan Tingkat Pendidikan yang Ditamatkan

Tingkat pendidikan yang dimiliki pekerja akan menjadi sinyal bagi pemberi kerja yang berusaha mencari pekerja dengan kemampuan yang sesuai. Ketidaksesuaian kualifikasi pendidikan mengindikasikan ketidaksesuaian antara ketersediaan pengetahuan dan keterampilan dengan yang dibutuhkan (Allen \& de Weert, 2007). Kesulitan proses penyesuaian permintaan dan penawaran tenaga kerja menyebabkan terjadinya kesenjangan keterampilan atau skill gap. Selain itu, peningkatan kualitas tenaga kerja yang ditawarkan tidak diikuti dengan meningkatnya permintaan tenaga kerja yang membutuhkan keterampilan tinggi dapat menyebabkan adanya ketidaksesuaian (mismatch). Mismatch dapat terjadi secara vertikal maupun horizontal. Vertical mismatch adalah ketidaksesuaian akibat kualifikasi pendidikan atau keterampilan yang dimiliki tenaga kerja lebih rendah atau lebih tinggi dari yang dipersyaratkan. Pada saat kualifikasi pendidikan yang dimiliki lebih tinggi maka tenaga kerja tersebut mengalami overeducation, sebaliknya apabila kualifikasi pendidikan yang dimiliki lebih rendah maka disebut undereducation. Sementara horizontal mismatch adalah ketidaksesuaian akibat jurusan pendidikan ataupun keterampilan yang dimiliki tenaga kerja berbeda dengan yang dibutuhkan atau dipersyaratkan dalam pekerjaannya (field of education mismatch).

Ketidaksesuaian kualifikasi pendidikan dengan pekerjaan (qualification mismatch) mendapat perhatian yang cukup besar karena dampaknya bagi tenaga kerja, perusahaan maupun perekonomian secara umum. Ketidaksesuaian tersebut dapat mempengaruhi tingkat upah, kepuasan kerja, dan perilaku mencari kerja tenaga kerja. Dalam beberapa penelitian, efek upah akibat qualification mismatch memiliki hasil yang berbeda-beda. Safuan dan Nazara (2005) melakukan identifikasi fenomena vertical mismatch pada pasar kerja Indonesia dengan menggunakan data SAKERNAS tahun 1996, 1999, dan 2002. Hasil penelitian mereka menemukan bahwa tenaga kerja yang overeducation berkorelasi negatif dengan penghasilannya, sebaliknya tenaga kerja yang undereducation berkorelasi positif dengan penghasilannya. Hal tersebut sejalan dengan beberapa penelitian di negara lain dimana tenaga kerja yang bekerja pada pekerjaan yang tidak sesuai dengan kualifikasi pendidikannya akan memperoleh upah yang lebih rendah (wage penalty) dibandingkan tenaga 
kerja dengan kualifikasi yang sama dan memiliki pekerjaan yang sesuai (Béduwé \& Giret, 2011; Dolton \& Silles, 2008; Nordin dkk., 2010) Dalam penelitiannya di Brazil, Reis (2017) menemukan bahwa perbedaan vertical mismatch memberikan efek upah yang berbeda. Tenaga kerja dengan tingkat pendidikan lebih tinggi daripada yang dibutuhkan pekerjaannya (overeducation) akan mendapatkan kelebihan upah (wage premium), sedangkan tenaga kerja yang tingkat pendidikannya lebih rendah (undereducation) akan mendapatkan wage penalty. Efek upah yang sama juga dirasakan tenaga kerja di Vietnam yang proporsi penduduknya lebih banyak berada di daerah pedesaan (Huy \& Binh, 2017).

Perusahaan yang mempekerjakan tenaga kerja dengan kualifikasi pendidikan lebih tinggi dibandingkan kebutuhan dapat meningkatkan produktivitas tenaga kerja tersebut. Namun, di sisi lain tenaga kerja tidak dapat menggunakan seluruh kemampuan yang dimiliki sehingga menyebabkan ketidakpuasan dalam bekerja dan berdampak pada menurunnya produktifitasnya (Allen \& van der Velden, 2001; Battu dkk., 1999; Sam, 2019). Ketidakpuasan dan efek upah yang dialami tenaga kerja dapat mendorongnya untuk berusaha mencari pekerjaan lain (Allen \& van der Velden, 2001; Béduwé \& Giret, 2011; Zakariya, 2017). Hal ini dapat meningkatkan perputaran (turnover) pegawai dalam perusahaan. Tingginya angka perputaran merupakan kerugian bagi perusahaan karena perusahaan akan membutuhkan tambahan biaya untuk melakukan rekrutmen serta pelatihan ulang. Selain itu, pegawai baru belum dapat bekerja dengan efektif menyebabkan produktivitas yang lebih rendah (Urbancova \& Linhartova, 2011)

Ketidaksesuaian yang terjadi pada tenaga kerja merupakan inefisiensi alokasi SDM karena dapat mempengaruhi produktivitas tenaga kerja. Apabila tenaga kerja yang tidak sesuai mengalami penurunan produktivitas dan memengaruhi output perusahaan, maka dapat menyebabkan turunnya perekonomian. Akibatnya, banyak terjadi pengangguran dan kesejahteraan masyarakat akan menurun.

Penentuan qualification mismatch dapat digunakan dengan metode statistik, metode normatif dan penilaian sendiri (self-assesment).
Pengukuran vertical mismatch yang umum dilakukan menggunakan metode statistik. Identifikasi vertical mismatch dengan pendekatan statistik dihitung menggunakan rata-rata dan standar deviasi lama bersekolah (Allen \& van der Velden, 2001; Duncan \& Hoffman, 1981; Safuan \& Nazara, 2005) Sementara untuk mengidentifikasi horizontal mismatch lebih umum digunakan metode penilaian sendiri (Allen \& van der Velden, 2001; Robst, 2007b, 2007a) Wolber (2003) dan Montt (2017) menggunakan pendekatan normatif yang mengukur kejadian horizontal mismatch berdasarkan pemetaan klasifikasi jabatan ( 3 digit ISCO $)^{1}$ dan klasifikasi jurusan pendidikan (2 digit ISCED) ${ }^{2}$.

Pada saat ini, penelitian mengenai qualification mismatch terutama horizontal mismatch belum banyak dilakukan di Indonesia. Selain itu, penelitian menggunakan metode normatif dalam identifikasi qualification mismatch juga masih terbatas. Hal ini membuka kesempatan untuk meneliti mengenai gambaran terjadinya qualification mismatch dengan metode identifikasi yang berbeda. Pada horizontal mismatch, identifikasi yang lebih detail juga akan dilakukan dengan pemetaan menggunakan klasifikasi jabatan 3 digit dan klasifikasi jurusan pendidikan 3 digit. Penelitian ini bertujuan untuk memeriksa tingkat kejadian qualification mismatch di Indonesia dengan menggunakan metode normatif. Selain itu, penelitian ini juga bertujuan untuk melihat pengaruh qualification mismatch terhadap upah tenaga kerja di Indonesia.

\section{TINJAUAN PUSTAKA}

Manusia adalah sumber daya yang memiliki dimensi kuantitatif (jumlah tenaga kerja, jumlah jam kerja) dan kualitatif (pengetahuan, keterampilan). Tenaga kerja sebagai faktor produksi memiliki kapasitas yang berbeda satu sama lain dan memiliki modal yang ada dalam

\footnotetext{
1 International Standard Classification of Occupation (ISCO) merupakan klasifikasi yang disusun International Labor Organisation (ILO). ISCO menyediakan informasi mengenai pekerja dan jabatannya

2 The International Standard Classification of Education (ISCED) adalah klasifikasi yang disusun oleh United Nations Educational, Scientific and Cultural Organization (UNESCO). ISCED menyediakan informasi mengenai pendidikan, baik tingkat, orientasi, maupun jurusan.
} 
dirinya (human capital). Manusia melakukan investasi pada modal manusia dengan beberapa cara, antara lain dengan menempuh pendidikan formal atau mengikuti pelatihan kerja. Dengan meningkatkan modal manusia maka diharapkan akan menghasilkan produktivitas yang lebih tinggi dan pada akhirnya mengarah pada penghasilan yang lebih tinggi (Becker, 1975; Schultz, 1961). Menurut human capital theory, mereka yang bekerja di bawah level pendidikan adalah mereka yang kurang produktif dibandingkan mereka yang bekerja sesuai levelnya. Oleh karena itu, perbedaan gaji yang diterima oleh tenaga kerja mismatch menggambarkan perbedaan dalam modal manusia yang dimiliki tiap-tiap individu.

Sattinger (1993) mengemukakan assignment theory yang menyebutkan bahwa alokasi optimal modal manusia adalah pada saat tenaga kerja ditugaskan menurut kemampuan mereka. Pekerja yang paling kompeten akan ditugaskan pada pekerjaan yang paling rumit dan paling kurang kompeten ditugaskan pada pekerjaan yang paling sederhana. Menurut teori ini, secara umum pendidikan yang lebih tinggi akan semakin meningkatkan produktivitas, namun produktivitas juga ditentukan oleh kesesuaian antara tingkat pendidikan dan tingkat pekerjaan. Bekerja pada pekerjaan dengan tingkat yang lebih rendah akan memengaruhi produktivitas pekerja yang akhirnya akan menyebabkan upah yang lebih rendah. Hartog (2000) menyebutkan ketidaksesuaian kualifikasi dan pekerjaan tenaga kerja merupakan keadaan sementara yang disebabkan oleh informasi tidak sempurna. Tenaga kerja tidak mempunyai informasi cukup mengenai lowongan pekerjaan yang tersedia dan akan berusaha untuk mencari pekerjaan yang lebih sesuai dengan kualifikasi atau keterampilannya (searching and matching). Oleh karena itu kejadian overeducation banyak ditemukan pada tenaga kerja baru yang sedang melalui fase transisi sekolah ke bekerja. Tenaga kerja baru belum memiliki informasi maupun pengalaman dalam pasar kerja sehingga mereka menerima pekerjaan yang tidak sesuai dan mempengaruhi tingkat pendapatannya.

Mismatch pada tenaga kerja adalah adanya ketidaksesuaian antara modal manusia yang dimiliki dengan pekerjaannya. Tenaga kerja dapat mengalami dua bentuk mismatch atau ketidaksesuaian, yaitu qualification mismatch dan skill mismatch (ILO, 2018). Qualification mismatch adalah ketidaksesuaian antara kualifikasi pendidikan yang dimiliki tenaga kerja dengan persyaratan kualifikasi pendidikan yang dibutuhkan pada pekerjaannya. Qualification mismatch terbagi menjadi 2 (dua) yaitu ketidaksesuaian pada tingkat pendidikan (vertical mismatch) dan ketidaksesuaian pada jurusan/bidang studi (horizontal mismatch). Ketidaksesuaian secara vertikal dimana tingkat pendidikan yang dimiliki lebih tinggi daripada tingkat pendidikan yang dibutuhkan oleh pekerjaan tersebut dinamakan overeducation, sebaliknya pada saat tingkat pendidikan yang dimiliki lebih rendah daripada tingkat pendidikan yang dibutuhkan oleh pekerjaan tersebut dinamakan undereducation.

Skill mismatch adalah ketidaksesuaian antara keterampilan yang dimiliki tenaga kerja dengan persyaratan keterampilan yang dibutuhkan pada pekerjaannya. Skill mismatch terdiri dari ketidaksesuaian keterampilan teknis (job-specific) technical skills), ketidaksesuaian keterampilan dasar, dan ketidaksesuaian portable skills (keterampilan yang dapat digunakan dalam berbagai jenis jabatan). Pada skill mismatch terdapat vertical mismatch yaitu keterampilan yang dimiliki melebihi persyaratan untuk melakukan pekerjaannya (overskilling) dan sebaliknya (underskilling).

Horizontal mismatch memiliki keterkaitan yang besar dengan skill mismatch. Pada saat seseorang mengambil jurusan pendidikan tertentu, maka dia mengharapkan akan mendapatkan keterampilan teknis yang dapat digunakan pada pekerjaannya di masa mendatang. Namun, meskipun jurusan pendidikan memberikan pengetahuan dan keterampilan untuk melakukan suatu pekerjaan, tidak semua keterampilan dapat diperoleh melalui pendidikan formal (Sellami dkk., 2018). Keterampilan teknis mungkin dapat diperoleh dengan lebih efisien melalui cara lain, seperti on-the-job training atau pelatihan. Sehingga pada saat terjadi ketidaksesuaian jurusan pendidikan maka dapat mengindikasikan terjadinya ketidaksesuaian keterampilan (Allen \& de Weert, 2007). 
Qualification mismatch pada pekerja sering diasosiasikan dengan pendapatan atau upah yang lebih rendah pada pekerja. Pada mismatch yang disebabkan sisi permintaan, pekerja terpaksa menerima pekerjaan yang tidak sesuai akibat tidak tersedianya lapangan pekerjaan yang sesuai (Kupets, 2016). Sebaliknya, mismatch yang diakibatkan dari penawaran, tenaga kerja memilih pekerjaan yang tidak sesuai dengan kualifikasi atau keterampilannya dengan alasan perubahan preferensi atau informasi yang dimilikinya (Robst, 2007a). Oleh karena itu, dalam kasus mismatch akibat permintaan, kita dapat mengharapkan adanya efek negatif terhadap upah (negative earnings effect) dan menyebabkan involuntary income penalty (Nordin dkk., 2010). Allen $\&$ van der Velden (2001) yang menggunakan data Belanda menyimpulkan bahwa tenaga kerja yang mengalami overeducation akan mendapatkan wage penalty atau upah yang lebih rendah, sedangkan tenaga kerja yang mengalami undereducation mendapatkan wage premium atau upah yang lebih tinggi. Namun hasil berbeda di dapatkan oleh Hartog (2000) yang menemukan bahwa overeducation memiliki pengaruh positif terhadap upah tenaga kerja di Belanda, Spanyol, dan Inggris. Penelitian di New Zealand juga menemukan bahwa overeducation berpengaruh positif pada upah, sedangkan undereducation berpengaruh negatif (Yeo \& Maani, 2017)

Penelitian mengenai dampak vertical mismatch pada negara berkembang juga memberikan hasil yang berbeda-beda. Safuan dan Nazara (2005) menemukan bahwa overeducation pada tenaga kerja di Indonesia berhubungan negatif dengan upah. Hal tersebut menunjukkan ada wage penalty pada tenaga kerja yang mengalami overeducation. Sebaliknya, undereducation menunjukkan hubungan positif dengan upah tenaga kerja. Efek upah yang sama dirasakan pada tenaga kerja yang mengalami vertical mismatch di Thailand (Pholphirul, 2017) dan Malaysia (Zakariya, 2014). Hasil yang berbeda di dapatkan pada penelitian di Brazil (Reis, 2017) dan Vietnam (Huy \& Binh, 2017). Tenaga kerja di Brazil dan Vietnam yang mengalami overeducation akan mendapatkan wage premium dan undereducation mendapatkan wage penalty.
Walaupun dampak overeducation lebih banyak diteliti, namun saat ini efek upah akibat horizontal mismatch juga mulai diperhatikan. Robst (2007a) mengemukakan tenaga kerja yang bidang pekerjaannya tidak sesuai dengan jurusannya akan mendapat wage penalty yang lebih besar dibandingkan vertical mismatch. Sejalan dengan penelitian Robst di Amerika Serikat, horizontal mismatch juga memiliki dampak negatif terhadap upah tenaga kerja baik di negara maju maupun negara berkembang (Nordin dkk., 2010; Pholphirul, 2017; Zakariya, 2014)

\section{DATA DAN METODOLOGI}

Penelitian ini menggunakan data yang berasal dari Survei Angkatan Kerja Nasional (SAKERNAS) yang dilakukan oleh Badan Pusat Statistik (BPS). Survei tersebut memberikan informasi mengenai gambaran keadaan angkatan kerja di Indonesia. Data yang digunakan merupakan periode Agustus 2018 yang menyediakan data mengenai upah, karakteristik sosiodemografi, maupun kualifikasi dan jurusan pendidikan pada level tenaga kerja. Penelitian ini tertarik untuk menganalisis upah tenaga kerja terkait pendidikan dan pekerjaannya untuk itu perlu dilakukan eliminasi sampel dengan beberapa kriteria. Unit analisis yang digunakan dalam penelitian ini adalah tenaga kerja dengan beberapa batasan antara lain merupakan angkatan kerja (berusia antara 15-64 tahun); berstatus buruh/karyawan/pegawai kecuali TNI/Polri; dan kualifikasi minimal pendidikan menengah ke atas. Setelah dilakukan eliminasi, sampel akhir adalah sebanyak 65.391.

Banyak penelitian dilakukan untuk mengetahui dampak mismatch terhadap upah tenaga kerja. Upah tenaga kerja yang mengalami mismatch baik secara vertikal maupun horizontal biasanya lebih rendah dibandingkan pekerja yang sesuai dengan pendidikan ataupun keterampilannya. Upah tenaga kerja dalam penelitian ini menggunakan proxy upah per jam karena memungkinkan kita untuk mengetahui upah tiap tenaga kerja dalam waktu kerja yang sama. Selain itu, upah per jam juga dapat mengindikasikan produktivitas tenaga kerja. Variabel upah per jam didapatkan dengan membagi upah sebulan dibagi jumlah jam kerja sebulan. 
Variabel independen yang dijadikan sebagai variabel utama penelitian ini adalah status mismatch tenaga kerja. Penelitian ini akan menggunakan pendekatan normatif yang lebih bersifat obyektif karena membandingkan persyaratan tiap pekerjaan dengan tingkat pendidikan maupun jurusan pendidikan yang dibutuhkan. Vertical mismatch (overeducation/undereducation) diidentifikasi dengan membandingkan golongan pekerjaan dan tingkat pendidikan yang dibutuhkan pekerjaan tersebut dengan tingkat pendidikan terakhir yang dimiliki tenaga kerja. Jenis dan golongan jabatan dalam pekerjaan di Indonesia disajikan dalam Klasifikasi Baku Jabatan Indonesia (KBJI) 2014 yang diadaptasi dari International Standard Classification of Occupation (ISCO) 2008.
Tingkat pendidikan mengacu pada International Standar Classification of Education (ISCED) 2011.

Identifikasi horizontal mismatch dilakukan dengan pemetaan antara klasifikasi pekerjaan 3 digit pada KBJI 2014 dan klasifikasi pendidikan 3 digit. Pemetaan ini mengacu pada penelitian yang dilakukan Wolber (2003) dan Montt (2017). Referensi yang digunakan untuk jurusan pendidikan adalah International Standard Classification of Education-Fields of Education and Training (ISCED-F) 2013. Namun, karena klasifikasi jurusan pendidikan di Indonesia tidak mengacu pada ISCED-F 2013 maka akan dilakukan rekodefikasi jurusan pendidikan Indonesia yang digunakan oleh Badan Pusat Statistik menjadi sesuai dengan ISCED-F 2013.

Tabel 1. Pemetaan Golongan Pekerjaan dan Tingkat Pendidikan

\begin{tabular}{|c|c|c|c|c|}
\hline \multirow[b]{2}{*}{ Golongan Pekerjaan } & \multicolumn{4}{|c|}{ Tingkat Pendidikan } \\
\hline & Sekolah Dasar & $\begin{array}{l}\text { Sekolah Menengah } \\
\text { Bawah dan Atas }\end{array}$ & $\begin{array}{l}\text { DI/DII/ } \\
\text { DIII }\end{array}$ & D4/S1/S2/S3 \\
\hline Manajer & under & under & under & match \\
\hline Profesional & under & under & match & match \\
\hline Teknisi dan Asisten Profesional & under & match & over & over \\
\hline Tenaga Tata Usaha & under & match & over & over \\
\hline Tenaga Usaha Jasa dan Tenaga Penjualan & under & match & over & over \\
\hline $\begin{array}{l}\text { Pekerja Terampil Pertanian, Kehutanan } \\
\text { dan Perikanan }\end{array}$ & under & match & over & over \\
\hline Pekerja Pengolahan, Kerajinan, dan YBDI & under & match & over & over \\
\hline Operator dan Perakit Mesin & under & match & over & over \\
\hline Pekerja Kasar & match & over & over & over \\
\hline
\end{tabular}

Sumber: ILO (2018)

Tabel 2. Pemetaan Jurusan Pekerjaan dan Pekerjaan yang Sesuai

\begin{tabular}{ll}
\hline Jurusan Pendidikan (ISCED-F 13 3 DIGITS) & Pekerjaan yang sesuai (KBJI 2014 3 DIGIT) \\
\hline \hline 011 Education & $134,232,233,234,235,531$ \\
\hline 021 Arts & $262,265,343,731,732$ \\
\hline 022 Humanities (except languages) & $262,263,341,343$ \\
\hline 023 Languages & 264 \\
\hline 031 Social and behavioural sciences & $121,122,134,241,242,243,263,331,335,341,411,521,522$ \\
\hline 032 Journalism and information & 262,264 \\
\hline 041 Business and administration & $121,122,134,142,143,241,242,243,331,332,333,334,335,411,412$, \\
\hline 042 Law & $413,421,422,431,432,441,521,522,523,524$ \\
\hline 051 Biological and related sciences & $261,335,341$ \\
\hline 052 Environment & 213,314 \\
\hline 053 Physical sciences & $131,335,621,622,921$ \\
\hline 054 Mathematics and statistics & $211,214,311$ \\
\hline
\end{tabular}




\begin{tabular}{ll}
\hline Jurusan Pendidikan (ISCED-F 13 3 DIGITS) & Pekerjaan yang sesuai (KBJI 2014 3 DIGIT) \\
\hline $\begin{array}{l}\text { 058 Inter-disciplinary programmes and qualifications } \\
\text { involving natural }\end{array}$ & $131,211,212,213,214,215,311,314,331,335,613,621,622,921$ \\
sciences, mathematics and statistics & $133,251,252,351,352$ \\
\hline 061 Information and Communication & \\
Technologies (ICTs) & $132,214,215,312,313,315,721,722,723,731,732,741$, \\
\hline 071 Engineering and engineering trades & $742,812,813,821$ \\
\hline 072 Manufacturing and processing & $132,312,313,751,752,753,754,811,812,813,814,815,816$, \\
& $817,818,821,931,932$ \\
\hline 073 Architecture and construction & $132,216,312,711,712,713,931$ \\
\hline 081 Agriculture & $131,335,611,612,613,631,632,633,921$ \\
\hline 082 Forestry & $131,621,921$ \\
\hline 083 Fisheries & $131,622,634,921$ \\
\hline 084 Veterinary & $225,324,516$ \\
\hline 088 Inter-disciplinary programmes and qualifications & $131,611,612,613,621,631,632,633,634,921$ \\
involving agriculture, forestry, fisheries and & \\
veterinary & \\
\hline 091 Health & $221,222,223,224,226,321,322,323,325,532$ \\
\hline 092 Welfare & $134,531,532$ \\
\hline 101 Personal services & $141,143,342,512,513,514,515,516,911,912,941$ \\
\hline 102 Hygiene and occupational health services & $313,515,516$ \\
\hline 103 Security services & 335,541 \\
\hline 104 Transport services & $511,831,832,833,834,835,933$ \\
\hline Sumber: Pengolahan penulis & \\
\hline
\end{tabular}

Statistik deskriptif yang menunjukkan rata-rata dan standar deviasi tiap variabel dapat dilihat pada Tabel 3 .

Tabel 3. Statistik Deskriptif

\begin{tabular}{llll}
\hline Variable & Obs & Mean & Std. Dev. \\
\hline \hline Upah per jam & 65.391 & $19.881,69$ & $21.027,56$ \\
\hline UNDEREDUC (1 jika undereducation, 0 lainnya) & 65.391 & 0,0537 & 0,2254 \\
\hline OVEREDUC (1 jika overeducation, 0 lainnya) & 65.391 & 0,2773 & 0,4477 \\
\hline FIELD (1 jika field of education mismatch, 0 lainnya) & 65.391 & 0,6476 & 0,4777 \\
\hline Pengalaman & 65.391 & 16,4451 & 10,6867 \\
\hline Jenis Kelamin (1 jika laki-laki, 0 lainnya) & 65.391 & 0,5924 & 0,4914 \\
\hline Status Perkawinan (1 jika kawin, 0 lainnya) & 65.391 & 0,6865 & 0,4639 \\
\hline Tempat Tinggal (1 jika perkotaan, 0 lainnya) & 65.391 & 0,6692 & 0,4705 \\
\hline Tingkat Pendidikan & & & 0,4974 \\
\hline Sekolah Menengah Atas (1 jika SMA, 0 lainnya) & 65.391 & 0,5505 & 0,2834 \\
\hline D1-D3 (1 jika D1-D3, 0 lainnya) & 65.391 & 0,0881 & 0,4704 \\
\hline D4-S1 (1 jika D4-S1, 0 lainnya) & 65.391 & 0,3305 & 0,1686 \\
\hline S2 (1 jika S2, 0 lainnya) & 65.391 & 0,0293 & 0,0404 \\
\hline S3 (1 jika S3, 0 lainnya) & 65.391 & 0,0016 & 0,4455 \\
\hline Pelatihan & 65.391 & 0,2730 & \\
\hline Sektor & 65.391 & & \\
\hline
\end{tabular}




\begin{tabular}{llll}
\hline Variable & Obs & Mean & Std. Dev. \\
\hline Sektor Pertanian (1 jika Pertanian, 0 lainnya) & 65.391 & 0,0311 & 0,1736 \\
\hline Sektor Manufaktur (1 jika Manufaktur, 0 lainnya) & 65.391 & 0,1899 & 0,3922 \\
\hline Sektor Jasa (1 jika Jasa, 0 lainnya) & 65.391 & 0,7790 & 0,4149 \\
\hline Pulau & & & \\
\hline Sumatera (1 jika Sumatera, 0 lainnya) & 65.391 & 0,2783 & 0,4482 \\
\hline Jawa-Bali (1 jika Jawa-Bali, 0 lainnya) & 65.391 & 0,3615 & 0,4805 \\
\hline Nusa Tenggara (1 jika Nusa Tenggara, 0 lainnya) & 65.391 & 0,0473 & 0,2122 \\
\hline Kalimantan (1 jika Kalimantan, 0 lainnya) & 65.391 & 0,1065 & 0,3085 \\
\hline Sulawesi (1 jika Sulawesi, 0 lainnya) & 65.391 & 0,1310 & 0,3374 \\
\hline Maluku (1 jika Maluku, 0 lainnya) & 65.391 & 0,0308 & 0,1727 \\
\hline Papua (1 jika Papua, 0 lainnya) & 65.391 & 0,0446 & 0,2063 \\
\hline PDRB & 65.391 & $770.143,1$ & $810.216,5$ \\
\hline Suber Pengolan
\end{tabular}

Sumber: Pengolahan penulis

\section{Spesifikasi Empiris}

Model empiris yang digunakan dalam penelitian ini diadaptasi dari penelitian sebelumnya yang dilakukan oleh Mincer (1974), Allen \& van der Valden (2001) dan Nordin dkk. (2010). Untuk mengestimasi pengaruh qualification mismatch terhadap upah tenaga kerja akan digunakan dengan metode regresi Ordinary Least Square (OLS). Spesifikasi empiris yang digunakan untuk mengestimasi dampak dari vertical mismatch terhadap upah terdapat pada persamaan 1.

Dengan Y merupakan variabel dependen yang ingin diteliti yaitu upah tenaga kerja; Undereduc merupakan kondisi mismatch dimana tingkat pendidikan yang dimiliki lebih rendah daripada persyaratan kerja; Overeduc merupakan kondisi mismatch dimana tingkat pendidikan yang dimiliki lebih tinggi daripada persyaratan kerja. Undereduc dan Overeduc merupakan dummy variabel mismatch dimana ketidaksesuaian/ mismatch dilabeli dengan angka 1 dan 0 untuk sebaliknya; X merupakan variabel-variabel kontrol seperti karakteristik modal manusia, karakteristik tenaga kerja, sektor, pulau, serta PDRB; dan $\varepsilon$ adalah error term.
Spesifikasi empiris yang digunakan untuk mengestimasi dampak dari horizontal mismatch terhadap upah terdapat pada persamaan 2.

Dengan Y merupakan variabel dependen yang ingin diteliti yaitu upah tenaga kerja; Field merupakan kondisi mismatch dimana jurusan pendidikan tidak sesuai dengan bidang pekerjaan. Field merupakan dummy variabel mismatch dimana ketidaksesuaian/mismatch dilabeli dengan angka 1 dan 0 untuk sebaliknya; $\mathrm{X}$ merupakan variabel-variabel kontrol seperti karakteristik modal manusia, karakteristik tenaga kerja, sektor, pulau, serta PDRB; dan $\varepsilon$ adalah error term.

Spesifikasi empiris yang digunakan untuk mengestimasi dampak dari ketidaksesuaian vertikal dan horizontal terhadap upah terdapat pada persamaan 3 .

Dengan Y merupakan variabel dependen yang ingin diteliti yaitu upah tenaga kerja; Undereduc merupakan kondisi mismatch dimana tingkat pendidikan yang dimiliki lebih rendah daripada persyaratan kerja; Overeduc merupakan kondisi mismatch dimana tingkat pendidikan yang dimiliki lebih tinggi daripada persyaratan kerja; Field merupakan kondisi mismatch dimana

$$
\begin{array}{r}
\ln (Y)_{i}=\beta_{0}+\beta_{1} \text { Undereduc }_{i}+\beta_{2} \text { Overeduc }_{i}+\beta_{3} X_{i}+\varepsilon_{i} \\
\ln (Y)_{i}=\beta_{0}+\beta_{1} \text { Field }_{i}+\beta_{2} X_{i}+\varepsilon_{i} \\
\ln (Y)_{i}=\beta_{0}+\beta_{1} \text { Undereduc }_{i}+\beta_{2} \text { Overeduc }_{i}+\beta_{3} \text { Field }_{i}+\beta_{4} X_{i}+\varepsilon_{i}
\end{array}
$$


jurusan pendidikan tidak sesuai dengan bidang pekerjaan. Overeduc, Undereduc dan Field merupakan dummy variabel mismatch dimana ketidaksesuaian/mismatch dilabeli dengan angka 1 dan 0 untuk sebaliknya; X merupakan variabel-variabel kontrol seperti karakteristik modal manusia, karakteristik tenaga kerja, sektor, pulau, serta PDRB; dan $\varepsilon$ adalah error term.

\section{HASIL DAN PEMBAHASAN}

\section{Tingkat Qualification Mismatch di Indonesia}

Pada tahun 2018, jumlah tenaga kerja yang memiliki kesesuaian antara tingkat pendidikan yang dimiliki dan diperlukan pekerjaannya sejumlah $67,5 \%$. Sementara sebanyak $32,5 \%$ tenaga kerja mengalami vertical qualification mismatch dimana $27,9 \%$ mengalami overeducation dan $4,6 \%$ undereducation. Selain itu, terdapat juga kejadian horizontal mismatch dimana hanya $31,6 \%$ tenaga kerja memiliki pekerjaan yang sesuai dengan jurusan pendidikannya, sedangkan sisanya sebesar $68,4 \%$ mengalami ketidaksesuaian dengan jurusan pendidikannya (field of education mismatch).

Tabel 4 menunjukkan persentase qualification mismatch dalam tiap kelompok umur. Kelompok umur yang paling sedikit mengalami overeducation adalah pada umur 15-19 tahun, karena hampir seluruh tenaga kerja pada kelompok umur tersebut merupakan lulusan sekolah menengah atas, sedangkan yang paling banyak mengalami overeducation adalah umur 25-29 tahun. Dalam hal undereducation, dapat dilihat persentase kejadian semakin banyak dimulai dari umur 30 tahun. Hal ini menunjukkan bahwa semakin tinggi usia tenaga kerja, tingkat undereducation semakin tinggi. Walaupun pendidikan yang dimiliki lebih rendah daripada persyaratan pekerjaannya, hal ini mungkin terjadi dengan bertambahnya pengalaman atau masa kerja seiring dengan pertambahan umur. Sebaliknya, semakin tinggi usia tenaga kerja, tingkat overeducation semakin menurun dan tingkat kesesuaian antara tingkat pendidikan dan pekerjaan semakin tinggi. Hal tersebut dapat menunjukkan adanya peningkatan jabatan yang sesuai tingkat pendidikannya dengan bertambahnya usia.
Berdasarkan kelompok umur, ketidaksesuaian antara jurusan dan bidang pekerjaan paling besar ada pada umur 60-64 tahun. Selain itu dapat juga dilihat bahwa kelompok umur umur 15-19 dan 20-24 tahun banyak mengalami field of education mismatch dibandingkan kelompok lain. Hal ini menunjukkan bahwa banyak tenaga kerja muda yang mengalami field of education mismatch. Hal tersebut dapat disebabkan oleh terbatasnya lapangan pekerjaan maupun informasi mengenai lowongan pekerjaan yang sesuai (Hartog, 2000).

Apabila dilihat berdasarkan jenis kelamin, baik laki-laki maupun perempuan memiliki persentase kesesuaian pekerjaan secara vertikal yang hampir sama. Namun kecenderungan pada laki-laki mengalami overeducation lebih tinggi dibandingkan perempuan. Sebaliknya, kecenderungan perempuan mengalami undereducation lebih tinggi dibandingkan lakilaki. Pada horizontal mismatch, persentase lakilaki yang mengalami ketidaksesuaian jauh lebih tinggi dibanding perempuan. Dalam penelitiannya terhadap lulusan pendidikan tinggi di Amerika Serikat, Robst (2007a) meneliti perbedaan tenaga kerja laki-laki dan perempuan dalam menerima pekerjaan yang tidak sesuai dengan kualifikasinya. Pada tenaga kerja perempuan, alasan menerima pekerjaan yang tidak sesuai dengan jurusan pendidikannya adalah terkait keluarga maupun perubahan dalam minat karirnya. Sementara alasan tenaga kerja laki-laki menerima pekerjaan di luar jurusan pendidikannya lebih disebabkan oleh adanya kesempatan gaji atau promosi yang lebih baik. Berdasarkan Tabel 4 juga dapat dilihat bahwa tenaga kerja yang berstatus tidak kawin lebih banyak mengalami overeducation dibandingkan tenaga kerja berstatus kawin. Selain itu, persentase yang berstatus tidak kawin mengalami field of education mismatch lebih tinggi daripada yang berstatus kawin.

Abel \& Deitz (2015) yang menemukan pasar tenaga kerja yang lebih besar meningkatkan kemungkinan untuk mendapatkan pekerjaan yang sesuai. Hal tersebut terkait dengan adanya aglomerasi dalam perkotaan yang menyebabkan terjadinya pemusatan pekerjaan/job pooling sehingga tenaga kerja dapat mencari pekerjaan yang lebih sesuai di antara variasi pekerjaan yang terdapat di perkotaan. Namun, tabulasi silang 
Tabel 4. Qualification Mismatch di Indonesia Berdasarkan Karakteristik Sosio Demografi Tenaga Kerja Tahun 2018

\begin{tabular}{|c|c|c|c|c|c|}
\hline & \multicolumn{3}{|c|}{ VERTICAL MISMATCH } & \multicolumn{2}{|c|}{ HORIZONTAL MISMATCH } \\
\hline & UNDER & МАТСН & OVER & МАТСН & FIELD OF EDUC \\
\hline \multicolumn{6}{|l|}{ Kelompok Umur } \\
\hline $15-19$ & $4,6 \%$ & $78,9 \%$ & $16,5 \%$ & $26,1 \%$ & $73,9 \%$ \\
\hline $20-24$ & $4,3 \%$ & $70,0 \%$ & $25,7 \%$ & $26,4 \%$ & $73,6 \%$ \\
\hline $25-29$ & $3,3 \%$ & $63,4 \%$ & $33,3 \%$ & $30,9 \%$ & $69,1 \%$ \\
\hline $30-34$ & $4,0 \%$ & $64,9 \%$ & $31,1 \%$ & $32,6 \%$ & $67,4 \%$ \\
\hline $35-39$ & $4,4 \%$ & $65,4 \%$ & $30,2 \%$ & $30,8 \%$ & $692 \%$ \\
\hline $40-44$ & $5,6 \%$ & $65,8 \%$ & $28,6 \%$ & $30,9 \%$ & $69,1 \%$ \\
\hline $45-49$ & $5,6 \%$ & $70,3 \%$ & $24,1 \%$ & $32,5 \%$ & $67,5 \%$ \\
\hline $50-54$ & $5,9 \%$ & $71,1 \%$ & $23,1 \%$ & $40,0 \%$ & $60,0 \%$ \\
\hline $55-59$ & $6,4 \%$ & $75,9 \%$ & $17,7 \%$ & $46,7 \%$ & $53,3 \%$ \\
\hline $60-64$ & $9,4 \%$ & $73,0 \%$ & $17,6 \%$ & $25,6 \%$ & $74,4 \%$ \\
\hline Total & $4,6 \%$ & $67,5 \%$ & $27,9 \%$ & $31,6 \%$ & $68,4 \%$ \\
\hline \multicolumn{6}{|l|}{ Jenis Kelamin } \\
\hline Perempuan & $5,9 \%$ & $67,2 \%$ & $26,9 \%$ & $43,5 \%$ & $56,5 \%$ \\
\hline Laki-laki & $3,7 \%$ & $67,6 \%$ & $28,6 \%$ & $24,4 \%$ & $75,6 \%$ \\
\hline Total & $4,6 \%$ & $67,5 \%$ & $27,9 \%$ & $31,6 \%$ & $68,4 \%$ \\
\hline \multicolumn{6}{|l|}{ Status Perkawinan } \\
\hline Tidak Kawin & $3,6 \%$ & $66,6 \%$ & $29,9 \%$ & $29,5 \%$ & $70,5 \%$ \\
\hline Kawin & $5,1 \%$ & $68,0 \%$ & $26,9 \%$ & $32,9 \%$ & $67,1 \%$ \\
\hline Total & $4,6 \%$ & $67,5 \%$ & $27,9 \%$ & $31,6 \%$ & $68,4 \%$ \\
\hline \multicolumn{6}{|l|}{ Tempat Tinggal } \\
\hline Pedesaan & $7,6 \%$ & $68,7 \%$ & $23,7 \%$ & $33,3 \%$ & $66,7 \%$ \\
\hline Perkotaan & $3,6 \%$ & $67,1 \%$ & $29,2 \%$ & $31,1 \%$ & $68,9 \%$ \\
\hline Total & $4,6 \%$ & $67,5 \%$ & $27,9 \%$ & $31,6 \%$ & $68,4 \%$ \\
\hline
\end{tabular}

Sumber: SAKERNAS (2018), diolah

antara kejadian mismatch dengan tempat tinggal tenaga kerja pada Tabel 4 menunjukkan hasil sebaliknya dimana persentase tenaga kerja yang tinggal di perkotaan mengalami overeducation dan field of education mismatch lebih tinggi daripada tenaga kerja yang berada di pedesaan. Hal ini mungkin terjadi akibat adanya persaingan kerja di perkotaan sehingga tenaga kerja lebih cenderung menerima pekerjaan yang tidak sesuai dengan kualifikasinya (Gaigné \& Sanch-Maritan, 2019).

Pada Tabel 5, dapat dilihat bahwa $61,4 \%$ lulusan D1-D3 mengalami overeducation. Artinya banyak lulusan diploma yang memiliki pekerjaan yang lebih lebih rendah kualifikasinya. Namun, secara horizontal, kelompok diploma paling banyak memiliki pekerjaan yang sesuai dengan jurusannya. Kejadian field of education mismatch terbesar berasal dari tingkat pendidikan sekolah lanjutan tingkat atas. Hal ini mungkin disebabkan karena kurangnya kualifikasi tingkat pendidikan sehingga menyebabkan mereka menerima pekerjaan walaupun tidak sesuai dengan jurusan pendidikannya.

Tabel 5 juga menunjukkan bahwa pada tenaga kerja yang tidak pernah mengikuti pelatihan dan memiliki sertifikat, memiliki persentase overeducation yang sedikit lebih tinggi dibandingkan yang memiliki sertifikat. Namun, pada tenaga kerja yang tidak pernah mengikuti pelatihan dan tidak memiliki sertifikat, persentase yang mengalami field of education mismatch lebih tinggi dibandingkan yang mengikuti pelatihan. Menurut human capital theory, tenaga kerja yang mengalami overeducation memiliki modal manusia yang lebih tinggi daripada tenaga kerja pada pekerjaan yang sama. Oleh karena itu, tenaga kerja yang overeducation cenderung merasa memiliki kualifikasi yang cukup dan tidak memerlukan pelatihan untuk menambah kemampuannya. Sementara tenaga kerja yang undereducation atau sesuai akan melakukan investasi dalam bentuk pelatihan untuk meningkatkan modal manusia yang dimilikinya (Hartog, 2000). Di sisi lain, tenaga 
Tabel 5. Qualification Mismatch di Indonesia Berdasarkan Karakteristik Modal Manusia Tenaga Kerja Tahun 2018

\begin{tabular}{lccccc} 
& \multicolumn{2}{c}{ VERTICAL MISMATCH } & HORIZONTAL MISMATCH \\
\cline { 2 - 5 } & UNDER & MATCH & OVER & MATCH & FIELD OF EDUC \\
\hline \hline Tingkat Pendidikan & & & & \\
\hline SMA sederajat & $7,0 \%$ & $76,6 \%$ & $16,4 \%$ & $18,4 \%$ & $81,6 \%$ \\
\hline D1-D3 & $3,6 \%$ & $35,0 \%$ & $61,4 \%$ & $53,2 \%$ & $46,8 \%$ \\
\hline D4-S1 & $0,0 \%$ & $56,0 \%$ & $44,0 \%$ & $52,7 \%$ & $47,3 \%$ \\
\hline S2 & $0,0 \%$ & $75,2 \%$ & $24,8 \%$ & $46,9 \%$ & $53,1 \%$ \\
\hline S3 & $0,0 \%$ & $95,2 \%$ & $4,8 \%$ & $24,4 \%$ & $75,6 \%$ \\
\hline Total & $\mathbf{4 , 6 \%}$ & $\mathbf{6 7 , 5 \%}$ & $\mathbf{2 7 , 9 \%}$ & $\mathbf{3 1 , 6 \%}$ & $\mathbf{6 8 , 4 \%}$ \\
\hline Pelatihan dan Sertifikasi & & & & \\
\hline Tidak Memiliki Sertifikat & $4,4 \%$ & $67,4 \%$ & $28,2 \%$ & $28,6 \%$ & $71,4 \%$ \\
\hline Memiliki Sertifikat & $5,0 \%$ & $67,9 \%$ & $27,1 \%$ & $42,1 \%$ & $57,9 \%$ \\
\hline Total & $\mathbf{4 , 6 \%}$ & $\mathbf{6 7 , 5 \%}$ & $\mathbf{2 7 , 9 \%}$ & $\mathbf{3 1 , 6 \%}$ & $\mathbf{6 8 , 4 \%}$ \\
\hline Sul & & & &
\end{tabular}

Sumber: SAKERNAS (2018), diolah

kerja yang tidak pernah mengikuti pelatihan dan memiliki sertifikat mengalami persentase kejadian field of education mismatch lebih tinggi daripada kelompok tenaga kerja yang pernah mengikuti pelatihan. Pada tenaga kerja yang tidak mengikuti pelatihan, sebanyak $71,4 \%$ mengalami ketidaksesuaian antara jurusan pendidikan dengan bidang pekerjaannya, sedangkan pada tenaga kerja yang mengikuti pelatihan, hanya $57,9 \%$ yang mengalami field of education mismatch. Hal ini menunjukkan bahwa pelatihan cukup berpengaruh pada kesempatan mendapatkan pekerjaan yang sesuai dengan jurusan pendidikannya.

\section{Pengaruh Qualification Mismatch terhadap Upah Tenaga Kerja}

Hasil estimasi pengaruh qualification mismatch terhadap upah dapat dilihat pada Tabel 6. Kolom 1 menunjukkan hubungan upah dengan variabel utama vertical mismatch. Hasil estimasi menunjukkan undereducation berhubungan positif dengan upah per jam dengan tingkat signifikansi 1\%. Koefisien undereducation adalah sebesar 0,0524, sehingga dapat diperkirakan bahwa walaupun pendidikan yang dimiliki lebih rendah dari persyaratan pekerjaannya, tenaga kerja akan mendapatkan wage premium sebesar 5,24\% dibandingkan tenaga kerja dengan tingkat pendidikan yang sama. Sebaliknya, overeducation berhubungan negatif dengan upah dengan tingkat signifikasi 1\%. Koefisien overeducation sebesar 0,0750 dimana tenaga kerja yang bekerja pada pekerjaan dengan persyaratan lebih rendah daripada tingkat pendidikan yang dimilikinya, akan mendapatkan wage penalty sebesar 7,50\% dibandingkan tenaga kerja dengan tingkat pendidikan yang sama.

Pada kolom 2, dilakukan estimasi upah dengan variabel utama horizontal mismatch. Field of education mismatch memiliki koefisien - 0,0680 sehingga diperkirakan bahwa tenaga kerja yang bekerja pada bidang yang tidak sesuai dengan jurusan pendidikannya, akan mendapatkan wage penalty atau upah per jam yang lebih kecil sebesar $6,80 \%$ dibandingkan tenaga kerja yang memiliki kesesuaian antara bidang pekerjaan dan jurusan pendidikannya.

Kolom 3 menunjukkan hasil estimasi upah dengan variabel utama vertical dan horizontal mismatch. Hasil estimasi spesifikasi model 3 konsisten dengan model 1 dan model 2, dimana undereducation berhubungan positif dengan upah per jam, sedangkan overeducation dan field of education mismatch berhubungan negatif dengan upah jam. Dari hasil estimasi dapat dilihat bahwa tenaga kerja yang mengalami undereducation akan mendapat wage premium sebesar $6,24 \%$, sedangkan tenaga kerja yang mengalami overeducation akan mengalami wage penalty sebesar $6,26 \%$. Hasil ini sesuai dengan penelitian sebelumnya di Indonesia oleh Safuan dan Nazara (2005) dimana undereducation berhubungan positif dan overeducation berhubungan negatif dengan penghasilan tenaga kerja. Hal ini juga sejalan dengan penelitian di Inggris (Groot, 1996), Malaysia (Zakariya, 2014) 
dan Thailand (Pholphirul, 2017). Hasil estimasi juga menunjukkan bahwa tenaga kerja yang mengalami ketidaksesuaian horizontal mendapat wage penalty $5,89 \%$ dibandingkan tenaga kerja yang bekerja pada bidang sesuai jurusan pendidikannya. Hal ini sejalan dengan hasil penelitian di beberapa negara yang menemukan field of education mismatch secara signifikan berhubungan negatif dengan upah (Nordin dkk., 2010; Robst, 2007b; Zakariya, 2014).

Efek negatif upah akibat field of education mismatch sedikit lebih kecil daripada overeducation. Namun, perlu diingat bahwa jumlah tenaga kerja yang mengalami field of education mismatch sebanyak $68,4 \%$ jauh lebih tinggi daripada kejadian overeducation sehingga hal ini perlu mendapat perhatian yang lebih. Tingkat qualification mismatch yang cukup tinggi di Indonesia dan efek negatifnya terhadap upah perlu menjadi perhatian karena tenaga kerja yang bekerja pada bidang yang tidak sesuai dengan kualifikasi maupun jurusannya tidak dapat memanfaatkan pengetahuan dan keterampilannya sehingga dapat berpotensi mengurangi produktivitasnya (Allen \& van der Velden, 2001; Somers dkk., 2019). Upaya untuk mengurangi terjadinya qualification mismatch antara lain dengan peningkatan kualitas pendidikan (Tao \& Hung, 2014), serta pendidikan maupun pelatihan yang terintegrasi dengan dunia kerja (Levels dkk., 2014).

Tabel 6 juga menyajikan hasil estimasi pengaruh beberapa variabel kontrol terhadap upah per jam tenaga kerja. Variabel tingkat pendidikan berhubungan positif dengan upah per jam. Hal ini sesuai dengan teori human capital dimana semakin tinggi tingkat pendidikan tenaga kerja maka semakin tinggi upah per jam yang diterimanya. Hasil estimasi juga menunjukkan pengalaman berhubungan positif dengan upah pada tingkat signifikansi $1 \%$, artinya semakin lama pengalaman tenaga kerja maka upah per jamnya meningkat. Selain pendidikan, pelatihan juga merupakan salah satu cara untuk meningkatkan modal manusia. Dengan mengikuti pelatihan, diharapkan dapat meningkatkan pengetahuan dan keterampilan yang dimiliki tenaga kerja. Hasil pengolahan data menunjukkan pelatihan juga secara signifikan berhubungan positif dengan upah per jam. Dengan melakukan pelatihan, maka diperkirakan upah per jam akan meningkat sebesar 16,7\%-17,3\%. Secara statistik, tenaga kerja yang mengikuti pelatihan juga lebih sedikit mengalami field of education mismatch dibandingkan tenaga kerja yang tidak memiliki pelatihan. Hal ini menunjukkan bahwa pelatihan merupakan salah satu investasi modal manusia yang penting dalam menentukan kesempatan kerja yang sesuai dan rate of return atas modal kapital yang dimilikinya.

Berdasarkan jenis kelamin, upah per jam juga berhubungan positif secara signifikan. Hasil pengolahan data menunjukkan masih adanya gender gap dimana tenaga kerja laki-laki memiliki upah per jam 18,4\%-19,2\% lebih tinggi dibandingkan tenaga kerja perempuan. Walaupun secara statistik, jumlah tenaga kerja laki-laki yang mengalami overeducation dan field of study mismatch lebih tinggi daripada tenaga kerja perempuan namun upah tenaga kerja laki-laki secara keseluruhan masih lebih tinggi daripada tenaga kerja perempuan. Selain itu, variabel status perkawinan juga secara signifikan berhubungan positif dengan upah per jam. Tenaga kerja yang berstatus kawin mendapatkan upah per jam 7,00\%-7,33\% lebih tinggi dibandingkan tenaga kerja yang tidak kawin. Berdasarkan tempat tinggal pekerja, dapat juga dilihat bahwa tempat tinggal berhubungan positif dengan upah dengan tingkat signifikansi 1\%. Dengan kata lain, tenaga kerja yang berada di perkotaan dapat memiliki upah lebih tinggi 14,9\%-15,6\% dibandingkan yang berada di pedesaan.

Apabila dianalisa berdasarkan sektor/ lapangan usaha, ditemukan bahwa sektor manufaktur memiliki hubungan yang positif dengan upah yang diterimanya. Upah per jam tenaga kerja yang berada pada sektor manufaktur berkisar $6,78 \%-8,38 \%$ lebih tinggi dibandingkan sektor pertanian. Sebaliknya pada sektor jasa, upah per jam yang diterima lebih rendah $12,2 \%-14,8 \%$ dibandingkan sektor pertanian. Hal ini menunjukkan bahwa tenaga kerja pada sektor manufaktur mendapatkan upah yang lebih tinggi dibandingkan sektor pertanian dan jasa.

Variabel pulau sebagai kontrol memiliki hasil yang berbeda. Variabel pulau Jawa-Bali tidak signifikan terhadap upah tenaga kerja. Apabila 
Tabel 6. Hasil Estimasi Cross-Section Ordinary Least Square Pada Semua Tenaga Kerja

\begin{tabular}{|c|c|c|c|}
\hline \multirow{2}{*}{ VARIABEL } & \multicolumn{3}{|c|}{ In Upah per Jam } \\
\hline & (1) & $(2)$ & (3) \\
\hline UNDEREDUC & $0.0524 * * *$ & & $0.0624 * * *$ \\
\hline (1 jika undereducation, 0 lainnya) & $(0.0145)$ & & $(0.0145)$ \\
\hline OVEREDUC & $-0.0750 * * *$ & & $-0.0626^{* * *}$ \\
\hline (1 jika overeducation, 0 lainnya) & $(0.00665)$ & & $(0.00672)$ \\
\hline FIELD & & $-0.0680 * * *$ & $-0.0589 * * *$ \\
\hline (1 jika field of education mismatch, 0 lainnya) & & $(0.00627)$ & $(0.00633)$ \\
\hline \multicolumn{4}{|l|}{ Tingkat Pendidikan (reference=SMA sederajat) } \\
\hline D1-D3 & $0.369 * * *$ & $0.309 * * *$ & $0.347 * * *$ \\
\hline (1 jika D1-D3, 0 lainnya) & $(0.0112)$ & $(0.0108)$ & $(0.0114)$ \\
\hline D4-S1 & $0.520 * * *$ & $0.469 * * *$ & $0.500 * * *$ \\
\hline (1 jika D4-S1, 0 lainnya) & $(0.00749)$ & $(0.00700)$ & $(0.00771)$ \\
\hline S2 & $1.023 * * *$ & $0.986 * * *$ & $1.010 * * *$ \\
\hline (1 jika S2, 0 lainnya) & $(0.0157)$ & $(0.0156)$ & $(0.0157)$ \\
\hline S3 & $1.310 * * *$ & $1.301 * * *$ & $1.311 * * *$ \\
\hline (1 jika S3, 0 lainnya) & $(0.0613)$ & $(0.0620)$ & $(0.0616)$ \\
\hline \multirow[t]{2}{*}{ Pengalaman } & $0.0328 * * *$ & $0.0329 * * *$ & $0.0328 * * *$ \\
\hline & $(0.00111)$ & $(0.00111)$ & $(0.00111)$ \\
\hline \multirow[t]{2}{*}{ Pengalaman kuadrat } & $-0.000233^{* * *}$ & $-0.000230 * * *$ & $-0.000237 * * *$ \\
\hline & $(2.73 \mathrm{e}-05)$ & $(2.74 \mathrm{e}-05)$ & $(2.73 \mathrm{e}-05)$ \\
\hline Pelatihan & $0.169 * * *$ & $0.173 * * *$ & $0.167 * * *$ \\
\hline (1 jika memiliki sertifikat, 0 lainnya) & $(0.00675)$ & $(0.00673)$ & $(0.00675)$ \\
\hline Jenis Kelamin & $0.185 * * *$ & $0.184 * * *$ & $0.192 * * *$ \\
\hline (1 jika laki-laki, 0 lainnya) & $(0.00604)$ & $(0.00605)$ & $(0.00608)$ \\
\hline Status Perkawinan & $0.0706^{* * *}$ & $0.0733 * * *$ & $0.0700 * * *$ \\
\hline (1 jika kawin, 0 lainnya) & $(0.00779)$ & $(0.00778)$ & $(0.00779)$ \\
\hline Tempat Tinggal & $0.155^{* * *}$ & $0.149 * * *$ & $0.156^{* * *}$ \\
\hline (1 jika perkotaan, 0 lainnya $)$ & $(0.00618)$ & $(0.00616)$ & $(0.00618)$ \\
\hline \multicolumn{4}{|l|}{$\begin{array}{l}\text { Sektor } \\
\text { (reference=Sektor Pertanian) }\end{array}$} \\
\hline Sektor Manufaktur & $0.0678 * * *$ & $0.0838 * * *$ & $0.0709 * * *$ \\
\hline (1 jika sektor manufaktur, 0 lainnya) & $(0.0149)$ & $(0.0149)$ & $(0.0149)$ \\
\hline Sektor Jasa & $-0.146^{* * *}$ & $-0.122 * * *$ & $-0.148^{* * *}$ \\
\hline (1 jika sektor jasa, 0 lainnya) & $(0.0145)$ & $(0.0144)$ & $(0.0145)$ \\
\hline \multicolumn{4}{|l|}{ Pulau (reference=Sumatera) } \\
\hline Jawa-Bali & -0.00611 & -0.00665 & -0.00645 \\
\hline (1 jika Jawa-Bali, 0 lainnya) & $(0.00909)$ & $(0.00908)$ & $(0.00908)$ \\
\hline Nusa Tenggara & $-0.199 * * *$ & $-0.198 * * *$ & $-0.200 * * *$ \\
\hline $\begin{array}{l}\text { (1 jika Nusa Tenggara, } \\
0 \text { lainnya) }\end{array}$ & $(0.0150)$ & $(0.0150)$ & $(0.0150)$ \\
\hline Kalimantan & $0.217 * * *$ & $0.218 * * *$ & $0.215^{* * *}$ \\
\hline (1 jika Kalimantan, 0 lainnya) & $(0.00906)$ & $(0.00907)$ & $(0.00905)$ \\
\hline Sulawesi & $-0.0674 * * *$ & $-0.0679 * * *$ & $-0.0671 * * *$ \\
\hline (1 jika Sulawesi, 0 lainnya) & $(0.0100)$ & $(0.0100)$ & $(0.0100)$ \\
\hline Maluku & $-0.0382 * *$ & $-0.0363 * *$ & $-0.0386 * *$ \\
\hline (1 jika Maluku, 0 lainnya) & $(0.0172)$ & $(0.0171)$ & $(0.0172)$ \\
\hline Papua & $0.460 * * *$ & $0.454 * * *$ & $0.455 * * *$ \\
\hline (1 jika Papua, 0 lainnya) & $(0.0126)$ & $(0.0126)$ & $(0.0126)$ \\
\hline \multirow[t]{2}{*}{ PDRB } & $7.64 \mathrm{e}-08 * * *$ & $7.71 \mathrm{e}-08 * * *$ & $7.63 \mathrm{e}-08^{* * *}$ \\
\hline & $(5.35 \mathrm{e}-09)$ & $(5.35 \mathrm{e}-09)$ & $(5.34 \mathrm{e}-09)$ \\
\hline \multirow[t]{2}{*}{ Konstanta } & $8.604 * * *$ & $8.629 * * *$ & $8.645 * * *$ \\
\hline & $(0.0164)$ & $(0.0169)$ & $(0.0170)$ \\
\hline \multicolumn{4}{|l|}{ Observasi } \\
\hline R-squared & 65,391 & 65,391 & 65,391 \\
\hline
\end{tabular}

Catatan: Standard error dalam kurung, signifikansi $* * * \mathrm{p}<0.01,{ }^{* *} \mathrm{p}<0.05,{ }^{*} \mathrm{p}<0.1$. 
dibandingkan dengan tenaga kerja di Sumatra, tenaga kerja di Kalimantan dan Papua memiliki upah yang lebih tinggi. Sementara tenaga kerja di pulau Nusa Tenggara, Sulawesi, dan Maluku memiliki upah yang lebih rendah dibandingkan tenaga kerja di pulau Sumatra. Hasil estimasi juga menunjukkan variabel PDRB berhubungan positif terhadap upah tenaga kerja, artinya semakin tinggi PDRB wilayah kerja tenaga kerja maka semakin tinggi upah tenaga kerja tersebut.

\section{KESIMPULAN}

Penelitian ini memberikan kontribusi empiris mengenai kejadian qualification mismatch di Indonesia dan efek upah yang diakibatkannya. Secara statistik, kejadian overeducation tertinggi berasal dari lulusan vokasi tingkat atas (D1-D3) pada kelompok usia 25-29 tahun. Sementara, kejadian horizontal mismatch tertinggi terdapat pada tenaga kerja usia muda lulusan sekolah menengah tingkat atas. Selain itu, tingkat horizontal mismatch juga lebih tinggi pada kelompok tenaga kerja yang tidak mengikuti pelatihan. Untuk mengurangi tingkat ketidaksesuaian pekerjaan dengan kualifikasi pendidikan yang dimiliki tenaga kerja, pemerintah perlu melakukan fasilitasi antara dunia pendidikan dan dunia kerja seperti program link and match dan pelatihan kerja yang lebih intensif. Pemerintah juga perlu terus meningkatkan kualitas pendidikan melalui perbaikan kurikulum maupun peningkatan kualitas tenaga pengajar. Selain kemampuan akademis, tenaga kerja juga perlu dilatih untuk memiliki keterampilan dasar seperti komputer atau bahasa Inggris untuk dapat meningkatkan daya saingnya.

Hasil pengolahan data dan analisa juga menunjukkan bahwa tenaga kerja yang mengalami undereducation akan mendapat wage premium atau upah yang lebih tinggi. Sementara tenaga kerja yang mengalami overeducation maupun field of education mismatch mendapatkan wage penalty atau upah yang lebih rendah dibandingkan tenaga kerja yang sesuai antara kualifikasi atau jurusan pendidikan dengan pekerjaannya. Hal ini dapat juga mengindikasikan bahwa tenaga kerja yang overeducation maupun field of education mismatch kurang produktif akibat ketidakmampuannya untuk memanfaatkan pengetahuan atau keterampilannya. Dalam jangka panjang produktifitas yang rendah dapat mempengaruhi output perusahaan dan menyebabkan turunnya perekonomian. Akibatnya, banyak terjadi pengangguran dan kesejahteraan masyarakat akan menurun. Oleh karena itu, perlu dilakukan langkah-langkah dalam mengatasi dampak qualification mismatch. Pemerintah dapat memfasilitasi penyelenggaraan pameran kerja sehingga tenaga kerja, terutama tenaga kerja baru, dapat memiliki informasi mengenai lowongan pekerjaan yang sesuai dengan kualifikasi pendidikannya. Selain itu, perlu untuk meningkatkan kualitas tenaga kerja dengan memfasilitasi pelatihan sehingga keterampilan tenaga kerja terus terbarui sejalan dengan perkembangan dunia kerja dan teknologi.

\section{REFERENSI}

Abel, J. R., \& Deitz, R. (2015). Agglomeration and job matching among college graduates. Regional Science and Urban Economics, 51, 14-24. https://doi.org/10.1016/j. regsciurbeco.2014.12.001

Allen, J., \& de Weert, E. (2007). What do educational mismatches tell us about skill mismatches? A cross-country analysis. European Journal of Education, 42(1), 59-73. https://doi.org/10.1111/j.14653435.2007.00283.x

Allen, J., \& van der Velden, R. (2001). Educational mismatches versus skill mismatches: Effects on wages, job satisfaction, and on-the-job search. Oxford Economic Papers, 53(3), 434-452. https://doi.org/10.1093/ oep/53.3.434

Battu, H., Belfield, C. R., \& Sloane, P. J. (1999). Overeducation among graduates: A cohort view. Education Economics, 7(1), 21-38. https://doi. org/10.1080/09645299900000002

Becker, G. (1975). Human capital: A theoretical and empirical analysis, with special reference to education, second edition. National Bureau of Economic Research, Inc. https://econpapers.repec.org/ RePEc:nbr:nberbk:beck75-1 
Béduwé, C., \& Giret, J. F. (2011). Mismatch of vocational graduates: What penalty on French labour market? Journal of Vocational Behavior, 78(1), 68-79. https:// doi.org/10.1016/j.jvb.2010.09.003

Di Gropello, E., Kruse, A., \& Tandon, P. (2011). Skills for the labor market in Indonesia. In Skills for the Labor Market in Indonesia. https://doi.org/10.1596/978-0-8213-8614-9

Dolton, P. J., \& Silles, M. A. (2008). The effects of over-education on earnings in the graduate labour market. Economics of Education Review, 27(2), 125-139. https:// doi.org/10.1016/j.econedurev.2006.08.008

Duncan, G. J., \& Hoffman, S. D. (1981). The incidence and wage effects of overeducation. Economics of Education Review, 1(1), 75-86. https://doi.org/10.1016/02727757(81)90028-5

Gaigné, C., \& Sanch-Maritan, M. (2019). City size and the risk of being unemployed. Job pooling vs. job competition. Regional Science and Urban Economics, 77(May), 222-238. https://doi.org/10.1016/j. regsciurbeco.2019.05.002

Groot, W. (1996). The incidence of, and returns to overeducation in the UK. Applied Economics, 28(10), 1345-1350. https://doi. org/10.1080/000368496327895

Hartog, J. (2000). Over-education and earnings: Where are we, where should we go? Economics of Education Review, 19(2), 131-147. https://doi.org/10.1016/S02727757(99)00050-3

Huy, L. Q., \& Binh, T. N. (2017). Qualification mismatch in the labor market and effects on earnings: Evidence from Vietnam. Unpublished IAB Paper. https://doi. org/10.1108/JED-09-2019-0032

ILO. (2018). Measurement of qualifications and skills mismatches of persons in employment. Geneva: International Labour Office 20th International Conference of Labour Statisticians ICLS/20/2018/Room document 15.

Kupets, O. (2016). Education-job mismatch in Ukraine: Too many people with tertiary education or too many jobs for low-skilled?
44, 125-147. https://doi.org/10.1016/j. jce.2015.10.005

Levels, M., van der Velden, R., \& Di Stasio, V. (2014). From school to fitting work: How education-to-job matching of European school leavers is related to educational system characteristics. Acta Sociologica, 57(4), 341-361. https://doi. org/10.1177/0001699314552807

Mincer, J. A. (1974). Schooling, experience, and earnings. NBER. http://www.nber.org/ books/minc74-1

Montt, G. (2017). Field-of-study mismatch and overqualification: Labour market correlates and their wage penalty. IZA Journal of Labor Economics, 6(1). https://doi.org/10.1186/ s40172-016-0052-x

Nordin, M., Persson, I., \& Rooth, D. O. (2010). Education-occupation mismatch: Is there an income penalty? Economics of Education Review, 29(6), 1047-1059. https://doi. org/10.1016/j.econedurev.2010.05.005

Pholphirul, P. (2017). Educational mismatches and labor market outcomes evidence from both vertical and horizontal mismatches in Thailand. Education and Training, 59(5), 534-546. https://doi.org/10.1108/ET-112016-0173

Reis, M. C. (2017). Educational mismatch and labor earnings in Brazil. International Journal of Manpower, 38(2), 180-197. https://doi.org/10.1108/IJM-02-2016-0030

Robst, J. (2007a). Education, college major, and job match: Gender differences in reasons for mismatch. Education Economics, 15(2), 159-175. https://doi. org/10.1080/09645290701263070

Robst, J. (2007b). Education and job match: The relatedness of college major and work. Economics of Education Review, 26(4), 397-407. https://doi.org/10.1016/j. econedurev.2006.08.003

Safuan, S., \& Nazara, S. (2005). Identifikasi fenomena 'Overeducation' di pasar kerja di Indonesia? Jurnal Ekonomi dan Pembangunan Indonesia, 6(1), 79-92. https://doi.org/10.21002/jepi.v6i1.152 
Sam, V. (2019). Impacts of educational mismatches on job satisfaction The case of university graduates in Cambodia. International Journal of Manpower, 41(1), 84-99. https:// doi.org/10.1108/IJM-07-2018-0229

Sattinger, M. (1993). Assignment models of the distribution of earnings. Journal of Economic Literature, 31(2), 831-880. https://doi.org/10.2307/2728516

Schultz, T. W. (1961). Investment in human capital. The American Economic Review, 51(1), 1-17.

Sellami, S., Verhaest, D., \& van Trier, W. (2018). How to measure field-of-study mismatch? A comparative analysis of the different methods. 32(4), 141-173. https://doi. org/10.1111/labr.12129

Somers, M. A., Cabus, S. J., Groot, W., \& van den Brink, H. M. (2019). Horizontal mismatch between employment and field of education: Evidence from a systematic literature review. Journal of Economic Surveys, 33(2), 567-603. https://doi.org/10.1111/joes.12271

Suharti. (2013). Trends in education in Indonesia. Education in Indonesia. Institute of Southeast Asian Studies (ISEAS).

Tao, H. L., \& Hung, C. Y. (2014). Vertical and horizontal educational mismatches of female graduates in Taiwan. Asian Economic Journal, 28(2), 181-199. https:// doi.org/10.1111/asej.12032

Urbancova, H., \& Linhartova, L. (2011). Staff turnover as a possible threat to knowledge loss. Journal of Competitiveness, 2011(3), 84-98

Wolbers, M. H. J. (2003). Job mismatches and their labour-market effects among school-leavers in Europe. European Sociological Review, 19(3), 249-266. https://doi.org/10.1093/ esr/19.3.249

Yeo, J. Z., \& Maani, S. A. (2017). Educational mismatches and earnings in the New Zealand labour market. New Zealand Economic Papers, 51(1), 28-48. https://doi. org/10.1080/00779954.2015.1114959

Zakariya, Z. (2014). Wage effect of over-education and mismatch in Malaysia: A random effect approach. Jurnal Ekonomi Malaysia, 48(2), 3-17. https://doi.org/10.17576/jem-20144802-01

Zakariya, Z. (2017). Job mismatch and on-the-job search behavior among university graduates in Malaysia. Asian Economic Journal, 31(4), 355-379. https://doi.org/10.1111/asej.12135 